\title{
WORK-RELATED RESPIRATORY SYMPTOMS IN BIRD ZOO KEEPERS — QUESTIONNAIRE DATA
}

\author{
SYLWIA ŚWIDERSKA-KIEŁBIK ${ }^{1}$, ANNA KRAKOWIAK ${ }^{1}$, MARTA WISZNIEWSKA ${ }^{1}$, WOJCIECH DUDEK ${ }^{2}$, \\ MONIKA KOWALCZYK ${ }^{1}$, JOLANTA WALUSIAK-SKORUPA ${ }^{1}$, KONRAD ŚLIWKIEWICZ ${ }^{1}$ and CEZARY PAŁCZYŃSKI ${ }^{1,2}$ \\ ${ }^{1}$ Nofer Institute of Occupational Medicine, Łódź, Poland \\ Department of Occupational Diseases and Toxicology \\ ${ }^{2}$ Nofer Institute of Occupational Medicine, Łódź, Poland \\ Centre of Occupational Allergy and Environmental Health
}

\begin{abstract}
Objectives: To investigate the risk factors for the development of airway diseases from occupational exposure to birds' allergens among Polish zoo garden keepers caring for birds. Methods: Two hundred workers responded to the questionnaire including the history of work-related symptoms, job characteristics, description of occupational exposure, information on smoking habit, contact with birds and animals at home and family history of allergic diseases. Results: General work-related symptoms were reported by 58 subjects (29\%), whereas work-related respiratory symptoms were found in 40 workers $(20 \%)$. The multivariate logistic regression analysis confirmed the significant role of positive family history of atopy and occupational contact with parrots either in the development of work-related symptoms or work-related respiratory allergic symptoms. Conclusions: The findings may confirm that work-related respiratory symptoms are an important health problem among zoo bird keepers in Poland.
\end{abstract}

Key words:

Allergens, Birds, Respiratory symptoms, Occupational exposure

\section{INTRODUCTION}

Professional bird keepers are at an increased risk of health problems from exposure to various occupational agents. Airborne contaminants in birds' cages include mixture of aerosolised agents, such as organic dust-skin debris, broken feather barbules, insect's remains, aerosolised food particles, birds' excreta, ammonia, and variety of viable bacteria, as well as airborne gram-negative bacteria and endotoxins [1-4]. Our data show that subjects working with birds are also exposed to disinfectants and latex allergens (LA). There are several reports suggesting that workers in this sector are at great risk for development of respiratory impairment [5-7]. Occupational allergy is an important health problem for bird keepers. Allergic conjunctivitis, rhinitis, asthma and skin symptoms may result from the contact with birds' allergens [8]. Feathers have been reported to cause also bird breeder's lung (extrinsic allergic alveolitis - EAA) [7]. Epidemiological data from Poland have not, so far, included information on the prevalence or the risk factors (e.g. the species of the bird, period of work, contact with animals in the past) for occupational allergic diseases due to exposure to high and low molecular weight allergens among zoo bird keepers.

\section{MATERIALS AND METHODS}

\section{Study population}

The study group included 200 subjects employed at zoo gardens located in metropolitan areas of Łódź, Warszawa, Gdańsk, Chorzów and Płock. A field study was carried out in 2008 and it comprised a medical examination and

Received: August 19, 2009. Accepted: October 16, 2009.

Address reprint request to: A. Krakowiak, Department of Occupational Diseases and Toxicology, Nofer Institute of Occupational Medicine, św. Teresy 8, 91-348 Łódź, Poland (e-mail: annakrak@imp.lodz.pl). 
a questionnaire survey. The study protocol gained approval of the Regional Biomedical Ethics Committee. All the participants gave their informed consent prior to the study.

\section{Questionnaire}

The questionnaire, supervised by a physician, was adapted from the instrument developed by the International Union against Tuberculosis and Lung Disease (IUATLD) [9]. The symptoms suggestive of asthma included dyspnoea, wheezing, chest tightness or cough under usual conditions or induced by exercise, exposure to cold air, smoke, dust or strong odours. The symptoms of rhinitis included sneezing, rhinorrhea, mucosal oedema and itching, while redness and oedema of eyelid, redness and oedema of conjunctiva, tearing and itching were indicative of allergic conjunctivitis. Respiratory, nasal and ophthalmic symptoms related with exposure to specific agents in the workplace and to agents out from work were also noted. The issues covered by the questionnaire included also job characteristics and description of occupational exposure. Two categories: smokers and nonsmokers were distinguished in the part enquiring about the smoking habit. The category of smokers encompassed current smokers and ex-smokers. Current smokers were defined as the subjects who reported smoking tobacco at time of survey and ex-smokers as those who had smoked daily and quit at least one month before the survey. Non-smokers category included only the subjects who had never smoked. Subjects having a pet in their childhood or before an onset of occupational contact with animals were defined as subjects with previous exposure to animals and/or birds.

\section{Diagnostic criteria}

The symptoms were considered to be work-related if they occurred after the contact with an occupational agent and receded or disappeared during weekends or holidays $[10,11]$.

\section{Statistical analysis}

Continuous variables were expressed as mean values \pm standard deviations (SD), while nominal variables as numbers and percentages. Odds ratio (OR) with $95 \%$ confidence interval was calculated for all the risk factors examined and separately for two outcomes: work-related symptoms and respiratory work-related symptoms using EPI INFO software (CDC, Atlanta, GA, USA). Factors found to be significant in the univariate analysis were included into the multivariate logisitic regression model (Statistica 99) to predict each of the different outcomes. The $\mathrm{p}$ value below 0.05 was adopted as the reference for selection of significant risk factors.

\section{RESULTS}

\section{Description of the study group}

The investigated group included 200 subjects - 109 males and 91 females, respectively, with the mean age of $43.27 \pm 13.59$ years for the entire group. The mean duration of exposure to occupational allergens was $16.23 \pm 12.08$ years (Table 1 ). The majority of subjects participating in the study, 122 workers (61\%), had a positive history of smoking (Table 2), while the positive family history was reported by 58 persons (29\%). One hundred thirty seven $(68.5 \%)$ subjects reported current contact with an animal at home, including 45 workers $(22,5 \%)$ reporting contact with a cat, $102(51 \%)$ with a dog, $23(11,5 \%)$ with a parrot, $16(8 \%)$ with a canary and 16 subjects (8\%) with other birds (duck, goose, hen, pigeon and birds of prey). Seventeen (8.5\%) workers reported contact only with birds at home. All questionnaire responses concerning animal and bird exposure at present and in the past are shown in Table 2.

One hundred thirty one workers $(65.5 \%)$ reported contact in the past with at least one species of birds included in the questionnaire, $55(27.5 \%)$ with a cat, $96(48 \%)$ with a dog, $39(19.5 \%)$ with a parrot, $19(9.5 \%)$ with a canary and 30 workers $(15 \%)$ with other birds.

One hundred forty eight workers (74\%) used latex gloves in the workplace, and 139 workers (69.5\%) were occupationally exposed to disinfectants during cleaning of the cages (Table 2).

General work-related symptoms were reported by 58 subjects (29\%), while work-related respiratory symptoms were observed in 40 workers (20\%). From questionnaire data, 
Table 1. Study population characteristics according to duration of occupational exposure to birds

\begin{tabular}{lc}
\hline \multicolumn{1}{c}{ Analysed parameter } & Number of subjects $(\%)$ \\
& $\mathrm{N}=200(100 \%)$ \\
\hline Age $($ Mean $\pm \mathrm{SD})$ (years) & $43.27 \pm 13.59$ \\
Sex ratio: men/women $[\mathrm{N}(\%)]$ & $109: 91(54.5 \%: 45.5 \%)$ \\
Duration of work with birds (Mean $\pm \mathrm{SD})$ (years) & $16.23 \pm 12.08$ \\
$\leq 5$ years & $40(20 \%)$ \\
6-10 years & $33(19.5 \%)$ \\
$\geq 11$ years & $121(60.5 \%)$ \\
\hline
\end{tabular}

Table 2. Study population characteristics

\begin{tabular}{|c|c|}
\hline Analysed parameter & $\begin{array}{l}\text { Number of subjects }(\%) \\
\qquad \mathrm{N}=200\end{array}$ \\
\hline \multicolumn{2}{|l|}{ Smoking status } \\
\hline current smoker & $71(35.5 \%)$ \\
\hline ex-smoker & $51(25.5 \%)$ \\
\hline non-smoker & $78(39 \%)$ \\
\hline Family history of atopy & $58(29 \%)$ \\
\hline Contact with animals and/or birds: & $137(68.5 \%)$ \\
\hline cat & $45(22.5 \%)$ \\
\hline $\operatorname{dog}$ & $102(51 \%)$ \\
\hline parrot & $23(11.5 \%)$ \\
\hline canary & $16(8 \%)$ \\
\hline other birds & $16(8 \%)$ \\
\hline Contact with animals and/or birds in the past: & $131(65.5 \%)$ \\
\hline cat & $55(27.5 \%)$ \\
\hline $\operatorname{dog}$ & $96(48 \%)$ \\
\hline parrot & $39(19.5 \%)$ \\
\hline canary & $19(9.5 \%)$ \\
\hline other birds (duck, goose, hen, pigeon and birds of prey) & $30(15 \%)$ \\
\hline Contact only with birds at home & $17(8.5 \%)$ \\
\hline Using latex gloves in the workplace & $148(74 \%)$ \\
\hline Using disinfectants in the workplace & $139(69.5 \%)$ \\
\hline
\end{tabular}

we found that all work-related symptoms quoted above were related with occupational exposure to birds' allergens. The authors did not find any case of work-related respiratory, skin or ophthalmic diseases due to disinfectants or LA. No case of EAA was reported in zoo bird workers. Regarding the questionnaire responses, nasal symptoms were reported most frequently by subjects working with birds. General nasal symptoms were found in 84 subjects (42\%) out of the total number of 200 workers, while work-related nasal symptoms were reported by 33 subjects (16.5\%) out of 200 workers. General ophthalmic symptoms were found in 57 subjects (28.5\%), while workrelated ophthalmic symptoms were noted in 27 workers (13.5\%). Isolated chest symptoms were reported by 51 
Table 3. Clinical symptoms: study group

\begin{tabular}{lcc}
\hline \multicolumn{1}{c}{ Symptom } & General symptoms & Work-related symptoms \\
\hline $\begin{array}{l}\text { Symptoms from the lower part } \\
\text { of the respiratory tract }\end{array}$ & $51(25.5 \%)$ & $7(4.2 \%)$ \\
Nasal symptoms & $84(42 \%)$ & $33(16.5 \%)$ \\
Ophthalmic symptoms & $57(28.5 \%)$ & $27(13.5 \%)$ \\
Dyspnoea & $25(12.5 \%)$ & $14(7 \%)$ \\
Cough & $43(21.5 \%)$ & $20(10 \%)$ \\
At least one symptom & $99(49.5 \%)$ & $40(20 \%)$ \\
$\quad$ from the respiratory tract & & $12(6 \%)$ \\
Skin symptoms & $32(16 \%)$ & \\
\hline
\end{tabular}

subjects (25.5\%), while the work-related asthmatic symptoms occurred in 7 subjects (4.2\%). General skin symptoms were found in 32 workers (16\%), while work-related skin diseases in 12 ones. The prevalence of work-related symptoms reported by workers is shown in Table 3 .

Statistical analysis revealed that subjects who had occupational contact with parrots more often complained of work-related symptoms in the workplace (Table 4). Also the multivariate logistic regression analysis confirmed the significant role of occupational contact with parrots in the development of work-related symptoms $(\mathrm{OR}=3.01$; 95\% CI: $1.48-6.13, \mathrm{p}=0,002)$. Univariate analysis showed that subject with positive family history of allergy more often reported work-related respiratory symptoms (Table 5). This observation was also confirmed by multivariate logistic regression analysis $(\mathrm{OR}=2.45,95 \%$ CI: 1.19-5.06, $\mathrm{p}=0.014)$.

Table 4. Analysis of risk factors for general work-related symptoms in the study population

\begin{tabular}{lccc}
\hline \multicolumn{1}{c}{ Factor } & $\begin{array}{c}\text { Subjects with work-related } \\
\text { symptoms } \\
\mathrm{N}=58\end{array}$ & $\begin{array}{c}\text { Subjects without work-related } \\
\text { symptoms } \\
\mathrm{N}=142\end{array}$ & OR \\
\hline Male & $26(44.83 \%)$ & $83(58.45 \%)$ & $0.58(0.3-1.12)$ \\
Female & $32(55.17 \%)$ & $59(41.55 \%)$ & $1.73(0.89-3.36)$ \\
Duration of work with birds & & & \\
$\leq 5$ years & $11(18.97 \%)$ & $29(20.42 \%)$ & $0.91(0.39-2.10)$ \\
6-10 years & $16(27.59 \%)$ & $23(16.20 \%)$ & $1.97(0.89-4.34)$ \\
$\geq 11$ years & $31(53.44 \%)$ & $90(63.38 \%)$ & $0.66(0.34-1.29)$ \\
Current smokers & $22(37.93 \%)$ & $49(34.51 \%)$ & $1.16(0.59-2.29)$ \\
Positive family history of atopy & $22(37.93 \%)$ & $36(25.35 \%)$ & $1.80(0.88-3.61)$ \\
Animals at home & $40(68.97 \%)$ & $97(68.31 \%)$ & $1.03(0.51-2.13)$ \\
Birds at home & $34(58.62 \%)$ & $40(28.17 \%)$ & $0.97(0.43-2.19)$ \\
Occupational exposure to: & & & \\
parrots & $39(67.24 \%)$ & $60(42.25 \%)$ & $2.81(1.41-5.65)^{*}$ \\
canaries & $28(48.27 \%)$ & $51(35.91 \%)$ & $1.67(0.85-3.23)$ \\
pigeons & $32(55.17 \%)$ & $60(42.25 \%)$ & $1.68(0.87-3.27)$ \\
other birds (duck, goose, hen, & $33(56.89 \%)$ & $67(47.18 \%)$ & $1.48(0.76-2.87)$ \\
and birds of prey) & & & \\
\hline
\end{tabular}

$* \mathrm{p}<0.05$. 
Table 5. Analysis of risk factors for work-related respiratory symptoms in the study population

\begin{tabular}{lccc}
\hline \multicolumn{1}{c}{ Risk factor } & $\begin{array}{c}\text { Subjects with work-related } \\
\text { respiratory symptoms } \\
\mathrm{N}=40\end{array}$ & $\begin{array}{c}\text { Subjects without work-related } \\
\text { respiratory symptoms } \\
\mathrm{N}=160\end{array}$ & OR \\
\hline Male & $16(40 \%)$ & $93(58.1 \%)$ & $0.48(0.22-1.03)$ \\
Female & $24(60 \%)$ & $67(41.9 \%)$ & $2,08(0.97-4.53)$ \\
Duration of work with birds & $7(17.5 \%)$ & $33(20.6 \%)$ & $0.82(0.28-2.11)$ \\
$\quad$ 5 years & $10(25 \%)$ & $29(18.13 \%)$ & $1.51(0.59-3.61)$ \\
6-10 years & $23(57.5 \%)$ & $98(61.3 \%)$ & $0.86(0.40-1.85)$ \\
$\geq 11$ years & $14(35 \%)$ & $57(35.6 \%)$ & $0.97(0.43-2.11)$ \\
Current smokers & $18(45 \%)$ & $40(25 \%)$ & $2.45(1.11-5.33)^{*}$ \\
Positive family history of atopy & $29(72.5 \%)$ & $108(67.5 \%)$ & $1.27(0.56-3.04)$ \\
Animals at home & $9(22.5 \%)$ & $33(20.6 \%)$ & $1.12(0.43-2.71)$ \\
Birds at home & & & $1.94(0.90-4.26)$ \\
Occupational exposure to: & $25(62.5 \%)$ & $74(46.25 \%)$ & $1.03(0.47-2.20)$ \\
parrots & $16(40 \%)$ & $63(39.38 \%)$ & $1.22(0.57-2.68)$ \\
canaries & $20(50 \%)$ & $72(45 \%)$ & $1.00(0.47-2.12)$ \\
pigeons & $20(50 \%)$ & $80(50 \%)$ & \\
other birds (duck, goose, hen, \\
and birds of prey)
\end{tabular}

$* p<0.05$.

\section{DISCUSSION}

Our results indicate that work in environment entailing occupational exposure to birds in zoo gardens is associated with increased frequency of respiratory and ophthalmic symptoms. From questionnaire data we found that most work-related symptoms had been associated with occupational exposure to birds' allergens. Feathers have been reported to cause allergic asthma, rhinitis and also atopic dermatitis [8,12], and are considered to be one of more frequent causes of IgE-mediated allergic reactions [6-8]. Samolinski [13] found that home exposure to animals (also to feathers) increased the intensity of allergic symptoms among pet owners - those data were presented in 2008, as the results of the completed project on epidemiology of allergic diseases in Poland - the ECAP study. Inhalable feather dust was shown to contain several allergenic components which cross-react with serum allergens/antigens of the same as well as of other bird species [14]. Well-defined major allergenic bands with molecular mass of $20-30 \mathrm{kDa}$ and $67 \mathrm{kDa}$ have been detected and identified in $\mathrm{IgE}$ immunoblots with feather extracts as well as with serum proteins of budgerigar, parrot, pigeon, canary, and hen [14]. However, the allergenic proteins may be found not only in feathers, but also in bird serum, droppings, skin scales, and in the case of pigeons in a waxy fine dust which coats the feathers (pigeon bloom). Also feather mites are the major source of soluble proteins derived from feathers, accounting for up to $10 \%$ of the total weight of the feather [15]. Considering group of subjects occupationally exposed to birds' allergens, work-related symptoms were reported by 58 of them (29\%), particularly work-related respiratory symptoms were found in 40 workers $(20 \%)$. Muller et al. [16] found that about $20 \%$ of poultry workers complained of respiratory symptoms. We have shown that the most common work-related symptoms reported by zoo workers taking care of birds were nasal ones. The present study revealed that 84 subjects $(42 \%)$ out of the total of 200 workers complained of nasal symptoms, whereas work-related upper airway symptoms were reported by 33 subjects $(16.5 \%)$ out of 200 total. The present study 
also revealed higher frequency of ophthalmic symptoms among zoo bird workers; general ophthalmic symptoms were found in 57 subjects (28.5\%), while work-related ocular symptoms in 27 subjects $(13.5 \%)$. Isolated chest symptoms were reported by 51 subjects $(25.5 \%)$, while the work-related asthmatic symptoms by 7 subjects $(4.2 \%)$. In our earlier studies published in 2002 [17], including 68 zoological garden keepers, we found occupational rhinitis due to feather exposure only in two cases, while occupational asthma only in one case. Also, in the study quoted above, Krakowiak et al. [17] noted that 6 zoo workers reported ophthalmic symptoms (allergic conjunctivitis) due to feather exposure. Rees et al. [18] studied 134 poultry workers and found that significantly more poultry workers than control persons complained of chest symptoms (increasing with longer exposure) and of eye, skin and nose irritation at work.

In our present study, logistic regression analysis confirmed that work-related respiratory symptoms occurred more often in subjects with positive family history of allergy. Several other studies described positive relationship between atopy and the development of IgE allergic reactions [19,20]. We have previously shown (data published in 2002), that occupational asthma and rhinitis due to feather allergens were observed only in atopic subjects [17]. Logistic regression analysis revealed that subjects who had occupational contact with parrots more often complained of allergic problems in the workplace. It should be mentioned that parrots have the largest number of pulviplumes [21]. These special feathers produce a very fine dust that resembles talcum powder, which can be inhaled and deposited in the lowest airways, as the particles' diameters are about $1 \mu \mathrm{m}$ [22]. Some authors suggest that the structure and composition of those feathers may be important for increased prevalence of sensitisation to birds' allergens [20].

In contrast to other authors, we did not find a significant relationship between the prevalence of work-related symptoms and the period of work with birds. Zuskin et al. [1] found that poultry workers exposed for more than 10 years had significantly higher prevalence of almost all chronic respiratory symptoms than those with shorter exposure. Contact with organic dust, especially due to close contact with pigeons, or other birds such as parrots, canaries, budgerigars, doves, parakeets or finches [22] may be responsible for the development of EAA. To our surprise, no case of EAA was reported in zoo bird workers. The authors did not find any case of work-related disease due to disinfectants and LA The present study does not confirm that current smokers are more predisposed either to the development of work-related diseases or work-related respiratory symptoms. Some data confirm the important role of smoking in the pathogenesis of occupational allergic diseases due to exposure to high molecular weight allergens, but the role of this agent in the development of EAA is still doubtful [23-25].

We conclude that work-related respiratory symptoms are an important heath problem among zoo bird keepers in Poland.

\section{REFERENCES}

1. Zuskin E, Mustajbegovic J, Neil Schachter E, Kern J, Rienzi N, Goswami S, et al. Respiratory function in poultry workers and pharmacologic characterization of poultry dust extract. Environ Res 1995;70:11-9.

2. Tauer-Reich I, Fruhmann G, Czuppon AB, Baur X. Allergens causing bird fancier's asthma. Allergy 1994;49: 448-53.

3. Mandallaz MM, de Weck AL, Dahinden CA. Bird-egg syndrome. Cross-reactivity between bird antigens and egg-yolk livetins in IgE-mediated hypersensitivity. Int Arch Allergy Appl Immunol 1988;87:143-50.

4. Gawlik R. Pigeon tick allergy. Alerg Astma Immun 2006;11(4):195-7 [in Polish].

5. Borghetti C, Magarolas R, Badorrey I, Radon K. Sensitization and occupational asthma in poultry workers. $\mathrm{J}$ Med Clin 2002;118(7):251-5.

6. Monteseirín J, Pérez-Formoso JL, Sánchez-Hernández MC, Hernández M, Bonilla I. Occupational contact dermatitis from canary grass seed. Contact Dermatitis 2002;47:247.

7. Cormier Y, Schuyler M. Hypersensitivity pneumonitis and organic dust toxic syndrome. In: Bernstein L, Chan-Yeung M, Malo JL, Bernstein DL, editors. Asthma in the work place. New York: Taylor \& Francis, 2006. 
8. Kilipiö K, Makinen-Kiljunen S, Häahtela T, Hannuksela M. Allergy to feathers. Allergy 1998;53:159-64.

9. Burney PGJ, Laitinen LA, Perdrizet S, Huckauf H, Tattersfield $\mathrm{AE}$, Chinn $\mathrm{S}$, et al. Validity and repeatability of the IUATLD Bronchial Symptoms Questionnaire: an international comparison. Eur Respir J 1989;940-5.

10. Johansson SG, Hourihane JO, Bousquet J, BruijnzeelKoomen C, Dreborg S, Haahtela T, et al. A revised nomenclature for allergy. An EAACI position statement from the EAACI nomenclature task force. Allergy 2001;56:813-24.

11. Reininger R, Swoboda I, Bohle B, Hauswirth AW, Valent P, Rumpold $\mathrm{H}$ et al. Characterization of recombinant cat albumin. Clin Exp Allergy 2003;33:1695-702.

12. Barr S, Sherman A. Asthma due to parakeet and canary feathers. J Allergy 1961;32:17-26.

13. Samoliński B. Epidemiology of Allergic Diseases in Poland, Report of ECRHS II and ISAAC study. Warszawa: Uniwersytet Medyczny w Warszawie; 2008 [in Polish].

14. Reich-Tauer I, Fruhmann G, Czuppon AB, Baur X. Allergens causing bird fancier's asthma. Allergy 1994;49(6):448-53.

15. Merrett TG, Colloff M, McSharry C, Merret J. Feather mite specific IgE antibodies are commonly found among pigeon keepers. Ann Allergy 1993;70:65.

16. Muller S, Bergmann KCh, Kramer H, Wuthe H. Sensitization, clinical symptoms and lung function disturbances among poultry farm workers in the German Democratic Republic. Am J Ind Med 1986;10:281-2.
17. Krakowiak A, Palczynski C, Walusiak J, Wittczak T, Ruta U, Dudek W, et al. Allergy to animal fur and feathers among zoo workers. Int ArchOccupEnvironHeath2002;75(Suppl):S113S116.

18. Rees D, Nelson G, Kiełkowski D, Wassrfall C, da Costa A. Respiratory health and immunological profile of poultry workers. S Afr Med J 1998;8(9):1110-7.

19. Martinez RO, Shams KA, Figueroa EA, Carmona MJC, Iturii JBG, Montes II, et al. Guidelines for occupational asthma. Arch Bronconeumol 2006;42(9):457-74.

20. Chan-Yeung M, Malo JL. Aetiological agents in occupational asthma. Eur Respir J 1994;7:346-71.

21. Tauer-Reich I, Fruhmann G, Czuppon AB, Baur X. Allergens causing bird fancier's athma. Allergy 1994;49:448-53.

22. Yoshizawa Y, Miyashita Y, Inoue T, Sumi Y, Miyazaki Y, Sato T, et al. Sequential evaluation of clinical and immunological findings in hypersensitivity pneumonitis: serial subclass distribution of antibodies. Clin Immunol Immunopathol 1994;73(3):330-7.

23. Warren CPW. Extrinsic allergic alveolitis: a disease commoner in non-smoker. Thorax. 1977;32:567-9.

24. Anderson K., Morrison S.M., Bourke S., Boyd G. Effect of cigarette smoking on the specific antibody response in pigeon fanciers. Thorax. 1988;43:798-800.

25. Zetterstrom O, Osterman K, Machado L, Johansson SG. Another smoking hazard: raised serum IgE concentration and risk of occupational allergy. Br Med J 1981;283:1215-7. 